\title{
Electronic Relaxation Pathways in Heavy-Atom-Free Photosensitizers Absorbing Near- Infrared Radiation and Exhibiting High Yields of Singlet Oxygen Generation
}

Luis A. Ortiz-Rodríguez, ${ }^{1}$ Sean J. Hoehn, ${ }^{1}$ Axel Loredo, ${ }^{2}$ Lushun Wang, ${ }^{2}$ Han Xiao, ${ }^{2,3,4}$ Carlos E. Crespo-Hernández*,1

${ }^{1}$ Department of Chemistry, Case Western Reserve University, Cleveland, Ohio, 44106, USA

${ }^{2}$ Department of Chemistry, Rice University, Houston, Texas, 77005, USA

${ }^{3}$ Department of Biosciences, Rice University, Houston, Texas, 77005, USA

${ }^{4}$ Department of Bioengineering, Rice University, Houston, Texas, 77005, USA

* email of corresponding author: carlos.crespo@case.edu

\section{Supporting Information}

\section{Experimental}

1. Chemicals. Thio-4-dimethylaminonaphthalamide (SDMNP) and Thio-based Nile Red (SNR) were prepared as described by Xiao and co-workers. ${ }^{1,2}$ The synthesis and characterization including ${ }^{1} \mathrm{H} \mathrm{NMR},{ }^{13} \mathrm{C}$ NMR, electrospray ionization mass (ESI-MS) and FT-IR spectroscopy can be found in the referenced literature. ${ }^{1,2}$ Both compounds were dissolved in dimethylsulfoxide (DMSO) and acetonitrile $(\mathrm{MeCN})$ and maintained under $\mathrm{N}_{2}$-saturated conditions to prevent spontaneous oxidation of the samples.

2. Steady-State Absorption Spectroscopy. Ground state absorption spectra were obtained at room temperature using a Cary 100 Bio UV-Visible absorption spectrophotometer (Varian Inc.).

3. Quantum Chemical Calculations. Density functional theory (DFT) and time-dependent density functional theory (TD-DFT) calculations were performed using the Gaussian $16^{3}$ suite of programs to gain information about the prospective decay channels available for both molecules. Ground-state geometry optimizations were performed at the B3LYP/IEFPCM/6-31+G(d,p) level of theory in DMSO and MeCN. ${ }^{4,5}$ The IEFPCM was used to model the bulk solvation (dielectric) effects to the system. ${ }^{6}$ Vertical excitation energies were calculated at the TD-PBE0/IEFPCM/6-31+G(d,p) level of theory in DMSO and $\mathrm{MeCN}{ }^{7}$ The first two excited singlet states for both molecules were optimized in Gaussian at the TD-PBE0/IEFPCM/6-31+G(d,p) level of theory. The lowest-energy triplet state was optimized at the TD-UPBE0/IEFPCM/6-31+G(d,p). The transient absorption spectra of the excited states were calculated in Orca $4.2 .1^{8}$ using the expectation value formalism ${ }^{9}$ at TD-PBE0/CPCM/6-31+G(d,p) obtaining the first 20 transitions from the state of interest and convoluting the transitions with a Gaussian with FWHM of $76 \mathrm{~nm}$. The Spin-Orbit Coupling constants (SOC) were obtained in Orca 4.2.1 at the TD-PBE0/ $\mathrm{CPCM} / 6-31+\mathrm{G}(\mathrm{d}, \mathrm{p})$ level of theory by using the Franck-Condon- (FC), the $\mathrm{S}_{1}$-minimum, and the $\mathrm{S}_{2}$-minimum geometries of both molecules in each solvent. In the case of SDMNP, the $\mathrm{NMe}_{2}$ was replaced by $\mathrm{NH}_{2}$ to speed up the calculations. 
4. Femtosecond Broadband Transient Absorption Spectroscopy. Femtosecond transient absorption spectroscopy (fs-TAS) was used to study the excited-state dynamics of SDMNP and SNR. The setup is described in detail in previous publications. ${ }^{10}$ Briefly, a Ti:Spapphire oscillator (Vitesse, Coherent, Santa Clara, CA, USA) seed a regenerative amplifier (Coherent Libra-HE) that generates a $100 \mathrm{fs}$ pulses at $800 \mathrm{~nm}$ with a repetition rate of $1 \mathrm{kHz}$ is used to pump a Traveling Optical Parametric Amplifier of Superfluorescence (TOPAS, Quantronix/Light Conversion, Vilnius, Lithuania). In this work, the TOPAS was tuned to 610 and $674 \mathrm{~nm}$. A translating $2 \mathrm{~mm} \mathrm{CaF}_{2}$ crystal was used to generate the white light continuum for probing (ca. 320 to $700 \mathrm{~nm}$ ). The setup employs a mechanical delay stage with a physical temporal limit of $3 \mathrm{~ns}$. The excitation pulses were set to a power of $1.75 \mathrm{~mW}$ (measured at the optical cell position) using a neutral density filter. A $2 \mathrm{~mm}$ optical cell was used. The solution was continuously stirred with a Tefloncoated magnetic stirrer. All solutions were kept below $10 \%$ degradation, as judged from the absorption at the maxima of the lowest-energy band of each compound. Data collection and processing made use of a homemade software (LabVIEW, National Instruments). Global and target kinetic analyses made use of the Glotaran software package. ${ }^{11,12}$ The fsTAS data were fit to a three-component sequential kinetic model (see Table S5 below).

\section{Supporting Results}

Table S1. Vertical excitation energies and energy gaps between relevant singlet and triplet excited states using the FC-geometry for SDMNP computed at the TD-PBE0/IEFPCM/6$31+\mathrm{G}(\mathrm{d}, \mathrm{p}) / / \mathrm{B} 3 \mathrm{LYP} / \mathrm{IEFPCM} / 6-31+\mathrm{G}(\mathrm{d}, \mathrm{p})$ in DMSO and MeCN

\begin{tabular}{lll}
\hline State & DMSO & MeCN \\
\hline $\mathrm{S}_{1}\left(\mathrm{n} \pi^{*}\right)$ & $2.30(0.0037)$ & $2.29(0.0001)$ \\
$\mathrm{S}_{2}\left(\pi \pi^{*}\right)$ & $2.31(0.2447)$ & $2.32(0.2369)$ \\
$\mathrm{T}_{1}\left(\pi \pi^{*}\right)$ & 1.64 & 1.64 \\
$\mathrm{~T}_{2}\left(\pi \pi^{*}\right)$ & 1.94 & 1.94 \\
$\mathrm{~T}_{3}\left(\mathrm{n} \pi^{*}\right)$ & 1.98 & 1.98 \\
$\mathrm{~T}_{4}\left(\mathrm{n} \pi^{*}\right)$ & 2.27 & 2.27 \\
$\Delta \mathrm{E}\left(\mathrm{S}_{2}-\mathrm{T}_{4}\right)$ & 0.04 & 0.05 \\
$\Delta \mathrm{E}\left(\mathrm{S}_{2}-\mathrm{T}_{3}\right)$ & 0.30 & 0.30 \\
$\Delta \mathrm{E}\left(\mathrm{S}_{1}-\mathrm{T}_{2}\right)$ & 0.40 & 0.40 \\
$\Delta \mathrm{E}\left(\mathrm{S}_{1}-\mathrm{T}_{1}\right)$ & 0.70 & 0.70 \\
$\Delta \mathrm{E}\left(\mathrm{T}_{3}-\mathrm{T}_{1}\right)$ & 0.34 & 0.34 \\
\hline
\end{tabular}

* Oscillator strengths are shown in parentheses. Values shown in brackets correspond to energy gap using the minima geometries of the $\mathrm{S}_{1}$ and $\mathrm{S}_{2}$. 
Table S2. Vertical excitation energies and energy gaps between relevant singlet and triplet excited states using the FC-geometry for SNR computed at the TD-PBE0/IEFPCM/6$31+\mathrm{G}(\mathrm{d}, \mathrm{p}) / / \mathrm{B} 3 \mathrm{LYP} / \mathrm{IEFPCM} / 6-31+\mathrm{G}(\mathrm{d}, \mathrm{p})$ in DMSO and $\mathrm{MeCN}$

\begin{tabular}{lll}
\hline State & DMSO & MeCN \\
\hline $\mathrm{S}_{1}\left(\mathrm{n} \pi^{*}\right)$ & $1.98(0.000)$ & $1.98(0.000)$ \\
$\mathrm{S}_{2}\left(\pi \pi^{*}\right)$ & $2.17(1.125)$ & $2.20(1.0918)$ \\
$\mathrm{T}_{1}\left(\pi \pi^{*}\right)$ & 0.96 & 0.96 \\
$\mathrm{~T}_{2}\left(\mathrm{n} \pi^{*}\right)$ & 1.74 & 1.73 \\
$\mathrm{~T}_{3}\left(\pi \pi^{*}\right)$ & 1.99 & 1.99 \\
$\Delta \mathrm{E}\left(\mathrm{S}_{2}-\mathrm{S}_{1}\right)$ & 0.19 & 0.22 \\
$\Delta \mathrm{E}\left(\mathrm{S}_{2}-\mathrm{T}_{2}\right)$ & 0.40 & 0.40 \\
$\Delta \mathrm{E}\left(\mathrm{S}_{1}-\mathrm{T}_{3}\right)$ & 0.01 & 0.01 \\
$\Delta \mathrm{E}\left(\mathrm{S}_{1}-\mathrm{T}_{1}\right)$ & 1.00 & 1.00 \\
\hline
\end{tabular}

* Oscillator strengths are shown in parentheses.

Vertical excitation energies (VEEs) and relevant energy gaps between the accessible singlet and triplet states upon NIR excitation of SDMNP and SNR are reported in Tables S1 and S2 in DMSO and MeCN. Upon excitation of both compounds with NIR wavelengths, the lowest energy $\pi \pi^{*}$ electronic state $\left(\mathrm{S}_{2}\right)$ is the one populated in both solvents, while the lowest-energy singlet state $\left(\mathrm{S}_{1}\right)$ state has $n \pi^{*}$ character and negligible oscillator strength for both molecules. As shown in Tables S1 and S2, there are four and three triplet states lower in energy than the $\mathrm{S}_{2}\left(\pi \pi^{*}\right)$ state in SDMNP and SNR, respectively. These results suggest that upon population of the $\mathrm{S}_{2}\left(\pi \pi^{*}\right)$ state, there are five and four prospective excited states available for deactivation of SDMNP and SNR, respectively.

Table S3. Calculated Spin-Orbit Coupling constants for SDMNP in DMSO and MeCN (italics) computed at the TD-PBE0/CPCM/6-31+G(d,p)//B3LYP/IEFPCM/6-31+G(d,p)

\begin{tabular}{llll}
\hline & FC-geometry & $\mathrm{S}_{1}$ (minimum) & $\mathrm{S}_{2}$ (minimum) \\
\hline $\mathrm{S}_{1}-\mathrm{T}_{2}$ & $1 \mathrm{~cm}^{-1}$ & $1 \mathrm{~cm}^{-1}$ & $1 \mathrm{~cm}^{-1}$ \\
$\mathrm{~S}_{1}-\mathrm{T}_{1}$ & $55 \mathrm{~cm}^{-1}$ & $58 \mathrm{~cm}^{-1}$ & $60 \mathrm{~cm}^{-1}$ \\
$\mathrm{~S}_{2}-\mathrm{T}_{4}$ & $9 \mathrm{~cm}^{-1}$ & $11 \mathrm{~cm}^{-1}$ & $9 \mathrm{~cm}^{-1}$ \\
$\mathrm{~S}_{2}-\mathrm{T}_{3}$ & $23 \mathrm{~cm}^{-1}$ & $48 \mathrm{~cm}^{-1}$ & $63 \mathrm{~cm}^{-1}$ \\
$S_{1}-T_{2}$ & $1 \mathrm{~cm}^{-1}$ & $1 \mathrm{~cm}^{-1}$ & $1 \mathrm{~cm}^{-1}$ \\
$S_{1}-T_{1}$ & $55 \mathrm{~cm}^{-1}$ & $58 \mathrm{~cm}^{-1}$ & $61 \mathrm{~cm}^{-1}$ \\
$S_{2}-T_{4}$ & $9 \mathrm{~cm}^{-1}$ & $12 \mathrm{~cm}^{-1}$ & $9 \mathrm{~cm}^{-1}$ \\
$S_{2}-T_{3}$ & $24 \mathrm{~cm}^{-1}$ & $49 \mathrm{~cm}^{-1}$ & $65 \mathrm{~cm}^{-1}$ \\
\hline
\end{tabular}


Table S4. Calculated Spin-Orbit Coupling constants for SNR in DMSO and MeCN (italics) computed at the TD-PBE0/CPCM/6-31+G(d,p)//B3LYP/IEFPCM/6-31+G(d,p)

\begin{tabular}{llll}
\hline & FC-geometry & $\mathrm{S}_{1}$ (minimum) & $\mathrm{S}_{2}$ (minimum) \\
\hline $\mathrm{S}_{1}-\mathrm{T}_{3}$ & $79 \mathrm{~cm}^{-1}$ & $77 \mathrm{~cm}^{-1}$ & $76 \mathrm{~cm}^{-1}$ \\
$\mathrm{~S}_{1}-\mathrm{T}_{2}$ & $0.3 \mathrm{~cm}^{-1}$ & $0.4 \mathrm{~cm}^{-1}$ & $0.3 \mathrm{~cm}^{-1}$ \\
$\mathrm{~S}_{1}-\mathrm{T}_{1}$ & $92 \mathrm{~cm}^{-1}$ & $102 \mathrm{~cm}^{-1}$ & $95 \mathrm{~cm}^{-1}$ \\
$\mathrm{~S}_{2}-\mathrm{T}_{3}$ & $2 \mathrm{~cm}^{-1}$ & $2 \mathrm{~cm}^{-1}$ & $3 \mathrm{~cm}^{-1}$ \\
$\mathrm{~S}_{2} \mathrm{~T}_{2}$ & $46 \mathrm{~cm}^{-1}$ & $60 \mathrm{~cm}^{-1}$ & $60 \mathrm{~cm}^{-1}$ \\
$S_{1}-T_{3}$ & $78 \mathrm{~cm}^{-1}$ & $77 \mathrm{~cm}^{-1}$ & $76 \mathrm{~cm}^{-1}$ \\
$S_{1}-T_{2}$ & $0.3 \mathrm{~cm}^{-1}$ & $0.4 \mathrm{~cm}^{-1}$ & $0.3 \mathrm{~cm}^{-1}$ \\
$S_{1}-T_{1}$ & $92 \mathrm{~cm}^{-1}$ & $103 \mathrm{~cm}^{-1}$ & $96 \mathrm{~cm}^{-1}$ \\
$S_{2}-T_{3}$ & $1 \mathrm{~cm}^{-1}$ & $2 \mathrm{~cm}^{-1}$ & $1 \mathrm{~cm}^{-1}$ \\
$S_{2}-T_{2}$ & $47 \mathrm{~cm}^{-1}$ & $61 \mathrm{~cm}^{-1}$ & $60 \mathrm{~cm}^{-1}$ \\
\hline
\end{tabular}

In Tables S3 and S4, the spin-orbit coupling constants (SOCs) between the two lowest energy singlet states and the four/three triplet states of SDMNP/SNR are presented, which were calculated from three key regions of their excited state potential energy surfaces (PESs): the FC, the $\mathrm{S}_{1}$-minimum, and the $\mathrm{S}_{2}$-minimum geometries. Considering the magnitude of the SOCs and El Sayed's rules, ISC to the triplet manifold in SDMNP should occur favorably between the $\mathrm{S}_{2}$ and $\mathrm{T}_{3}$ states and between the $\mathrm{S}_{1}$ and $\mathrm{T}_{1}$ states, independent of the regions of the PESs or solvent used, while ISC between the $\mathrm{S}_{2}$ and the $\mathrm{T}_{4}$ states may also play a smaller role. In the case of SNR, ISC to the triplet manifold is predicted to occur more efficiently between the $S_{2}$ and $T_{2}$ states, the $S_{1}$ and $T_{1}$ states, and the $S_{1}$ and $T_{3}$ states, independent of the regions of the PESs or solvent used.
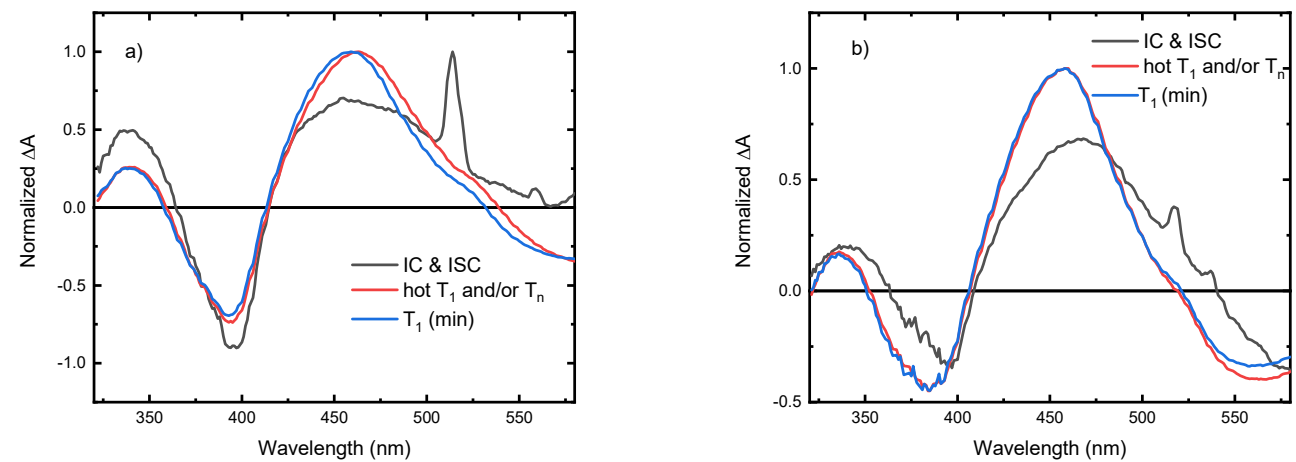

Figure S1. EADS for SDMNP in a) DMSO and b) MeCN extracted from the global and target analyses.

Evolution-associated difference spectra (EADS) extracted from the global and target analyses of SDMNP upon excitation with $610 \mathrm{~nm}$ in DMSO and MeCN are reported in Figure S1. As can be seen in Figure S1, the extracted EADS of SDMNP in both solvents are in good agreement with the spectral evolution reported in Figure 2. Hence, in both solvents we assign the black EADS to a combination of internal conversion (IC) from the $\mathrm{S}_{2}$ to the $\mathrm{S}_{1}$ and ISC to the 
triplet manifold, the red EADS is assigned to the vibrationally excited $\mathrm{T}_{1}$ state and/or $\mathrm{T}_{\mathrm{n}}$ states, and the blue EADS is assigned to the $\mathrm{T}_{1}$-minimum (see the main text for details).

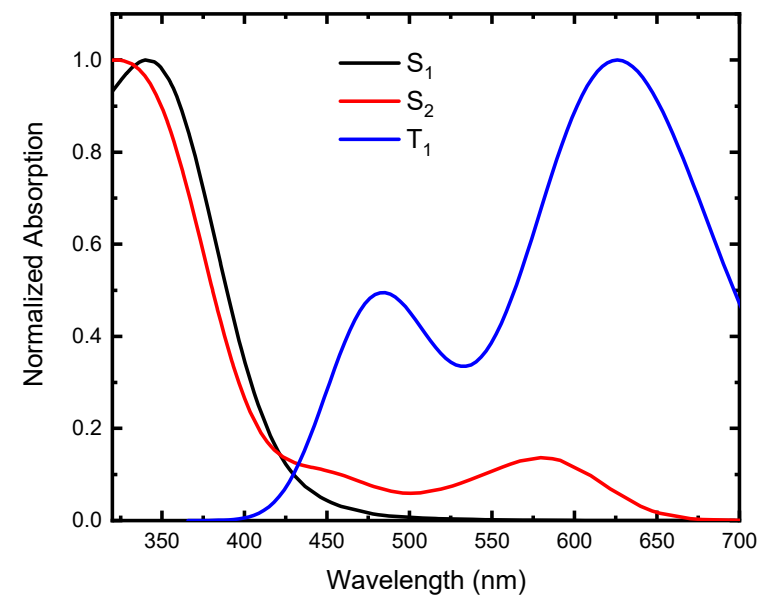

Figure S2. Calculated EAS of $\mathrm{S}_{1}, \mathrm{~S}_{2}$ and $\mathrm{T}_{1}$ states of SDMNP obtained at the TDPBE0/CPCM/6-31+G(d,p)//B3LYP/IEFPCM/6-31+G(d,p) in DMSO.

The calculated excited state absorption spectra (EAS) of the $\mathrm{S}_{1}, \mathrm{~S}_{2}$ and $\mathrm{T}_{1}$ states of SDMNP in DMSO are reported in Figure S2. As can be seen in Figure S2, all three states overlap significantly. This is in good agreement with the experimental data reported in Figure 2 and 3 , where it is evident that there is significant overlap of multiple transient species at early time delays and thus, these EAS were extremely useful in the disentanglement of the excited state dynamic of SDMNP. 

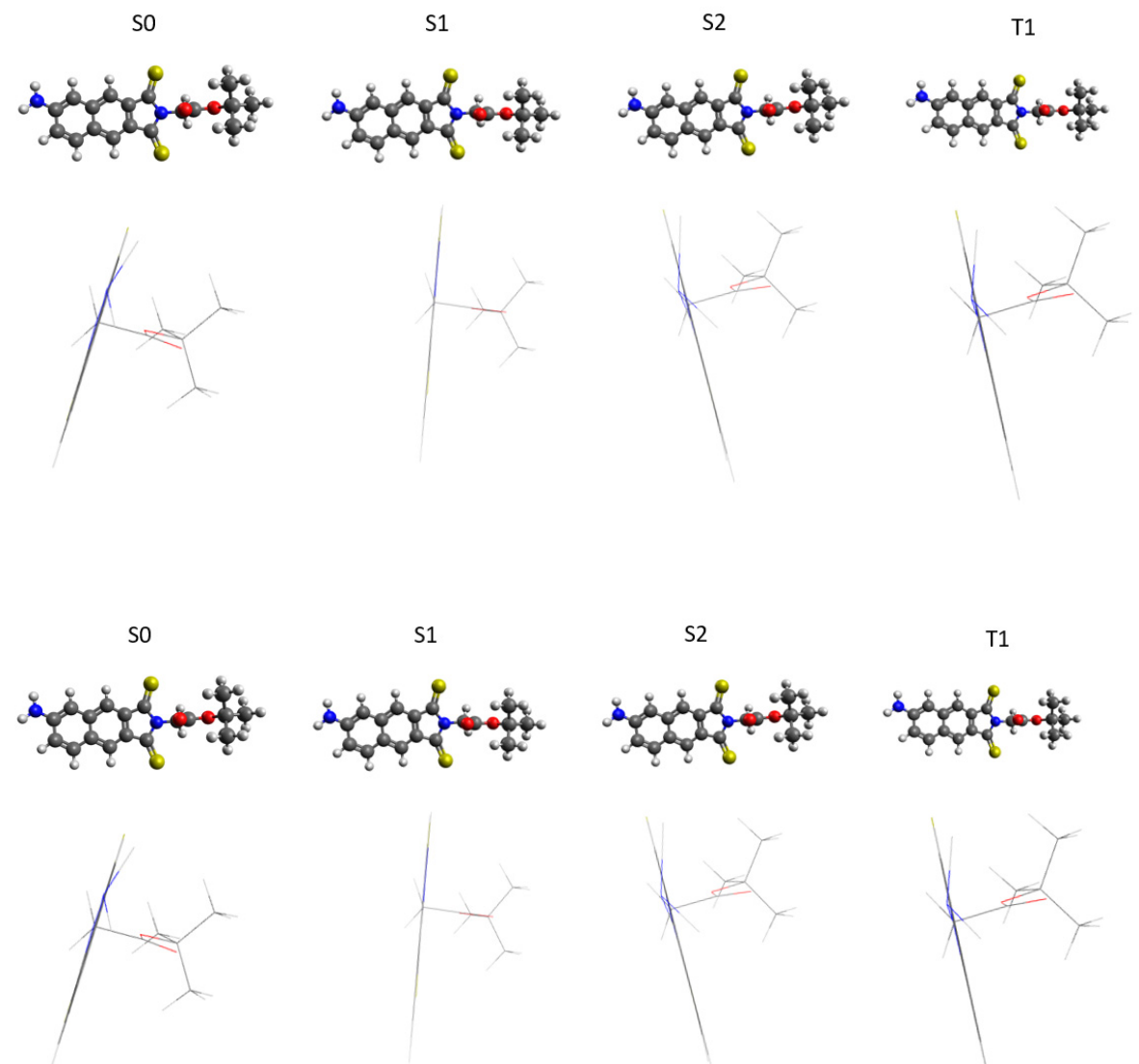

Figure S3. Optimized structures of the $\mathrm{S}_{0}, \mathrm{~S}_{1}, \mathrm{~S}_{2}$ and $\mathrm{T}_{1}$ for SDMNP in DMSO (top) and MeCN (bottom).

As can be seen in Figure $S 3$, the minima structures of the $\mathrm{S}_{0}, \mathrm{~S}_{1}, \mathrm{~S}_{2}$ and $\mathrm{T}_{1}$ for SDMNP in DMSO and MeCN are mostly planar, with only the amino group exhibiting some puckering in the case of the $\mathrm{S}_{0}, \mathrm{~S}_{2}$ and $\mathrm{T}_{1}$. Besides the puckering of the amino group, the other major structural difference is the change of the bond length of both carbon-sulfur bonds. In the case of the carbonsulfur bond pointing to the top of the page, the bond lengths are $1.66(1.66), 1.68(1.68), 1.71(1.71)$ and 1.70 (1.71) angstroms for $\mathrm{S}_{0}, \mathrm{~S}_{1}, \mathrm{~S}_{2}$ and $\mathrm{T}_{1}$, respectively. In the case of the carbon-sulfur bond pointing to the bottom of the page, the bond lengths are $1.66(1.66), 1.67(1.67), 1.71(1.71)$ and 1.71 (1.71) angstroms for $\mathrm{S}_{0}, \mathrm{~S}_{1}, \mathrm{~S}_{2}$ and $\mathrm{T}_{1}$, respectively. Values for $\mathrm{MeCN}$ are the values in parentheses. 


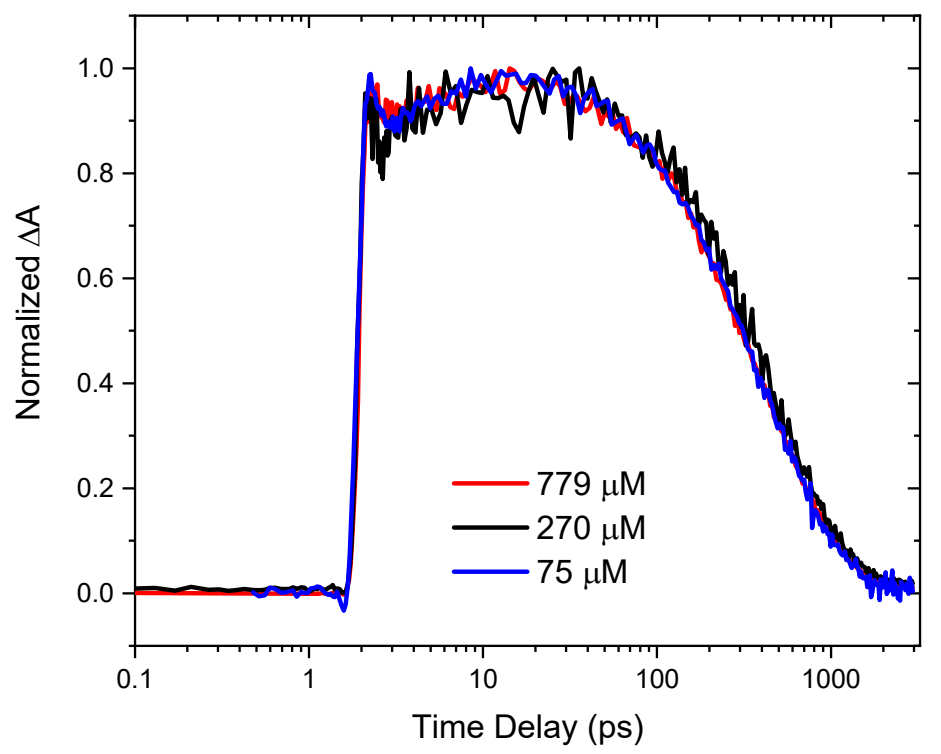

Figure S4. Normalized $460 \mathrm{~nm}$ decay traces of SDMNP in DMSO at different concentrations.

In Figure S4, the Normalized $460 \mathrm{~nm}$ decay traces of SDMNP in DMSO at different concentrations are shown. By varying the concentration from 75 to $779 \mu \mathrm{M}$, it was examined whether the triplet decay is due to triplet self-quenching at the concentration used in the experiments. No change in the triplet decay lifetime was observed in this concentration range (Figure S4), supporting the idea that the decay is due to an intrinsic process.
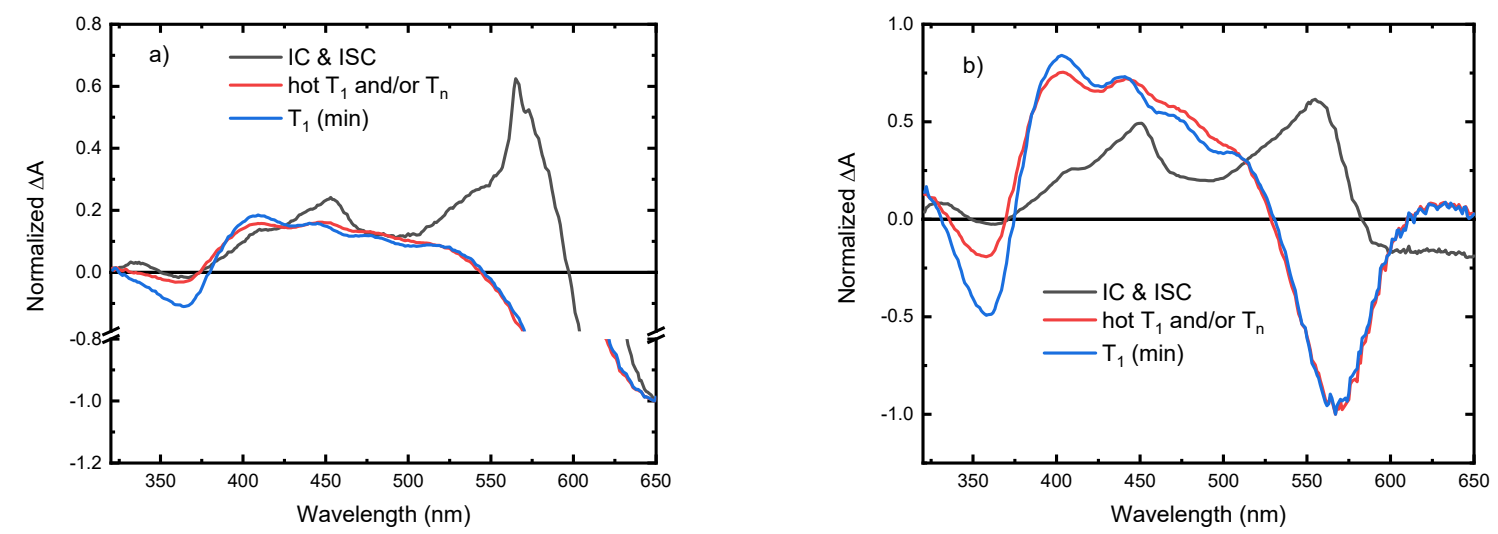

Figure S5. EADS for SNR in a) DMSO and b) MeCN extracted from the global and target analyses.

EADS extracted from the global and target analyses of SNR upon excitation with $674 \mathrm{~nm}$ in DMSO and MeCN are reported in Figure S5. As can be seen in Figure S5, the extracted EADS of SNR in both solvents are in good agreement with the spectral evolution reported in Figure 4. 
Hence, in both solvents we assign the black EADS to a combination of internal conversion (IC) from the $S_{2}$ to the $S_{1}$ and ISC to the triplet manifold, the red EADS is assigned to a vibrationally excited $\mathrm{T}_{1}$ state and/or $\mathrm{T}_{\mathrm{n}}$ states, and the blue EADS is assigned to the $\mathrm{T}_{1}$-minimum (see the main text for details).

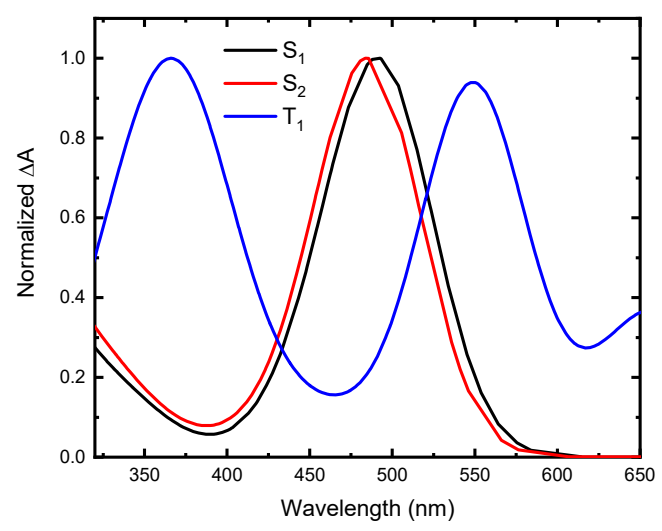

Figure S6. Calculated EAS of $\mathrm{S}_{1}, \mathrm{~S}_{2}$ and $\mathrm{T}_{1}$ states of SNR obtained at the TD-PBE0/CPCM/6-31 $+\mathrm{G}(\mathrm{d}, \mathrm{p}) / / \mathrm{B} 3 \mathrm{LYP} / \mathrm{IEFPCM} / 6-31+\mathrm{G}(\mathrm{d}, \mathrm{p})$ in DMSO.

The calculated excited state absorption spectra (EAS) of the of $\mathrm{S}_{1}, \mathrm{~S}_{2}$ and $\mathrm{T}_{1}$ states of SNR in DMSO are reported in Figure S6. As can be seen in Figure S6, all three states overlap significantly. This is in good agreement with the experimental data reported in Figure 3 and 4, where it is evident that there is significant overlap of multiple transient species at early time delays and thus, these EAS were extremely useful in the disentanglement of the excited state dynamic of SNR. 

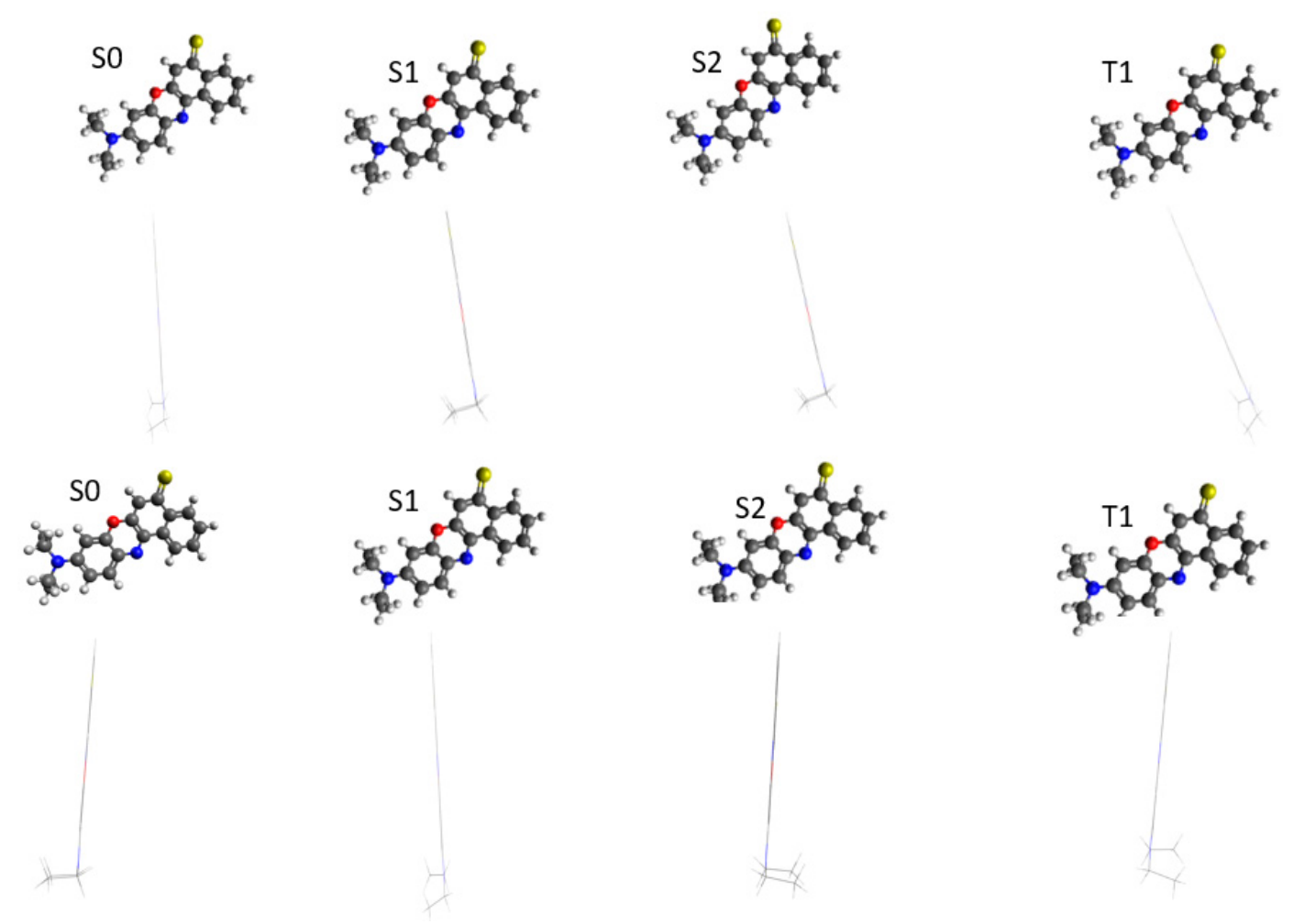

Figure S7. Optimized structures of the $\mathrm{S}_{0}, \mathrm{~S}_{1}, \mathrm{~S}_{2}$ and $\mathrm{T}_{1}$ for SNR in DMSO (top) and MeCN (bottom).

As can be seen in Figure $\mathrm{S} 7$, the minima structures of the $\mathrm{S}_{0}, \mathrm{~S}_{1}, \mathrm{~S}_{2}$ and $\mathrm{T}_{1}$ for $\mathrm{SNR}$ in DMSO and MeCN are planar, with only the ethyl groups out of the plane. The other major structural difference is the change of the bond length of the carbon-sulfur bond. The bond lengths are 1.70 (1.70), 1.75(1.76), 1.71 (1.71) and 1.72 (1.72) angstroms for $\mathrm{S}_{0}, \mathrm{~S}_{1}, \mathrm{~S}_{2}$ and $\mathrm{T}_{1}$, respectively. Values for $\mathrm{MeCN}$ are the values in parentheses.

Table S5. Lifetimes obtained from global and targeted kinetic analyses

\begin{tabular}{lllll}
\hline Lifetime & SDMNP (DMSO) & SDMNP (MeCN) & SNR (DMSO) & SNR (MeCN) \\
\hline$\tau_{1}$ & $580 \pm 40 \mathrm{fs}$ & $210 \pm 40 \mathrm{fs}$ & $500 \pm 40 \mathrm{fs}$ & $540 \pm 40 \mathrm{fs}$ \\
$\tau_{2}$ & $5 \pm 1 \mathrm{ps}$ & $50 \pm 2 \mathrm{ps}$ & $110 \pm 10 \mathrm{ps}$ & $41 \pm 6 \mathrm{ps}$ \\
$\tau_{3}$ & $440 \pm 20 \mathrm{ps}$ & $1100 \pm 40 \mathrm{ps}$ & $\infty(>3 \mathrm{~ns})^{\mathrm{a}}$ & $\infty(>3 \mathrm{~ns})^{\mathrm{a}}$ \\
\hline
\end{tabular}

${ }^{a}$ A long-lived lifetime ( $>3 \mathrm{~ns}$ ) was required to model the transient signal. Changing its magnitude from 3 to $20 \mathrm{~ns}$ does not affect the other two lifetimes. 
Table S6. Vertical excitation energies FC-geometry for DMNP computed at the TDPBE0/IEFPCM/6-31+G(d,p)//B3LYP/IEFPCM/6-31+G(d,p) in DMSO

\begin{tabular}{ll}
\hline State & DMSO \\
\hline $\mathrm{S}_{1}\left(\pi \pi^{*}\right)$ & $3.30(0.1047)$ \\
$\mathrm{S}_{2}\left(\pi \pi^{*}\right)$ & $3.67(0.1895)$ \\
$\mathrm{T}_{1}\left(\pi \pi^{*}\right)$ & 2.46 \\
$\mathrm{~T}_{2}\left(\pi \pi^{*}\right)$ & 2.63 \\
$\mathrm{~T}_{3}\left(\mathrm{n} \pi^{*}\right)$ & 3.24 \\
$\mathrm{~T}_{4}\left(\mathrm{n} \pi^{*}\right)$ & 3.64 \\
\hline
\end{tabular}

Table S7. Vertical excitation energies FC-geometry for NR computed at the TDPBE0/IEFPCM/6-31+G(d,p)//B3LYP/IEFPCM/6-31+G(d,p) in DMSO

\begin{tabular}{ll}
\hline State & DMSO \\
\hline $\mathrm{S}_{1}\left(\pi \pi^{*}\right)$ & $2.54(0.9592)$ \\
$\mathrm{S}_{2}\left(\mathrm{n} \pi^{*}\right)$ & $3.19(0.000)$ \\
$\mathrm{T}_{1}\left(\pi \pi^{*}\right)$ & 1.35 \\
$\mathrm{~T}_{2}\left(\pi \pi^{*}\right)$ & 2.49 \\
$\mathrm{~T}_{3}\left(\mathrm{n} \pi^{*}\right)$ & 2.82 \\
$\mathrm{~T}_{4}\left(\mathrm{n} \pi^{*}\right)$ & 3.00 \\
\hline
\end{tabular}

Table S8. Calculated Spin-Orbit Coupling constants for DMNP in DMSO computed at the TDPBE0/CPCM/6-31+G(d,p)//B3LYP/IEFPCM/6-31+G(d,p)

\begin{tabular}{ll}
\hline & FC-geometry \\
\hline $\mathrm{S}_{1}-\mathrm{T}_{3}$ & $0.5 \mathrm{~cm}^{-1}$ \\
$\mathrm{~S}_{1}-\mathrm{T}_{2}$ & $0.7 \mathrm{~cm}^{-1}$ \\
$\mathrm{~S}_{1}-\mathrm{T}_{1}$ & $0.3 \mathrm{~cm}^{-1}$ \\
$\mathrm{~S}_{2}-\mathrm{T}_{4}$ & $0.5 \mathrm{~cm}^{-1}$ \\
$\mathrm{~S}_{2}-\mathrm{T}_{3}$ & $0.3 \mathrm{~cm}^{-1}$ \\
$\mathrm{~S}_{2}-\mathrm{T}_{2}$ & $0.2 \mathrm{~cm}^{-1}$ \\
$\mathrm{~S}_{2}-\mathrm{T}_{1}$ & $0.5 \mathrm{~cm}^{-1}$ \\
\hline
\end{tabular}

Table S9. Calculated Spin-Orbit Coupling constants for NR in DMSO computed at the TDPBE0/CPCM/6-31+G(d,p)//B3LYP/IEFPCM/6-31+G(d,p)

\begin{tabular}{ll}
\hline & FC-geometry \\
\hline $\mathrm{S}_{1}-\mathrm{T}_{1}$ & $0.4 \mathrm{~cm}^{-1}$ \\
$\mathrm{~S}_{1}-\mathrm{T}_{2}$ & $0.5 \mathrm{~cm}^{-1}$ \\
\hline
\end{tabular}

VEEs and SOCs using the FC-geometry for the oxygen congeners of SDMNP and SNR are reported in Tables S6 to S9. As shown in Table S6 and S7, the first two excited singlet states of dimethylaminonaphtalamide (DMNP) and the first two triplet states $\pi \pi^{*}$ character. There are also available for deactivation, two excited triplet states with $n \pi^{*}$ character. Therefore, considering El Sayed's rules, ISC would only be expected to occur between the $\mathrm{S}_{2}-\mathrm{T}_{4}$ and $\mathrm{S}_{2}-\mathrm{T}_{3}$. However, the SOCs between these states are negligible and thus, ISC to the triplet manifold should not be a 
pathway that contributes significantly to the deactivation of DMNP. In the case of NR, the $\mathrm{S}_{2}$ state has $n *$ character and is not expected to be populated directly. Thus, the lowest energy singlet state that can be populated directly is the $S_{1}\left(\pi \pi^{*}\right)$ character. There are two excited states available for deactivation from the $S_{1}\left(\pi \pi^{*}\right)$, the $T_{1}\left(\pi \pi^{*}\right)$ and the $T_{2}\left(\pi \pi^{*}\right)$. Based in El Sayed's rules, ISC to the triplet manifold should not occur favorably between these states because the transition would involve states with the same type of orbitals. This is in good agreement with the calculated SOCs reported in Table S9. Thus, like in the case of DMNP, ISC to the triplet manifold should not be a pathway that contributes significantly to the deactivation of NR. These results suggest that the excellent photophysical and photochemical properties exhibit by SDMNP and SNR are due to the straightforward oxygen-by-sulfur substitution of the carbonyl groups.

\section{III.Cartesian Coordinates of Relevant States}

\section{$\mathrm{S}_{0}$ SDMNP}

$\begin{array}{llll}\mathrm{C} & -0.73198 & 1.25771 & -0.53756 \\ \mathrm{C} & 0.51484 & 0.73661 & -0.09667 \\ \mathrm{C} & 0.59462 & -0.67677 & 0.18948 \\ \mathrm{C} & -0.54586 & -1.48597 & 0.02534 \\ \mathrm{C} & -1.76016 & -0.94786 & -0.40787 \\ \mathrm{C} & -1.83174 & 0.45080 & -0.68863 \\ \mathrm{H} & -0.80685 & 2.31877 & -0.75934 \\ \mathrm{H} & -0.47549 & -2.54897 & 0.24165 \\ \mathrm{H} & -2.77531 & 0.87196 & -1.02509 \\ \mathrm{~N} & -2.89198 & -1.72168 & -0.51689 \\ \mathrm{H} & -2.76586 & -2.72409 & -0.57442 \\ \mathrm{H} & -3.63748 & -1.37621 & -1.10732 \\ \mathrm{C} & 1.65351 & 1.56221 & 0.05954 \\ \mathrm{C} & 2.83576 & 0.99733 & 0.48760 \\ \mathrm{C} & 2.91902 & -0.39681 & 0.77001 \\ \mathrm{C} & 1.83686 & -1.22762 & 0.63000 \\ \mathrm{H} & 1.58911 & 2.62486 & -0.15755 \\ \mathrm{H} & 1.91416 & -2.28894 & 0.84776 \\ \mathrm{C} & 4.14039 & 1.58587 & 0.73407 \\ \mathrm{C} & 4.29038 & -0.68527 & 1.19639\end{array}$




$\begin{array}{llll}\mathrm{N} & 4.95775 & 0.53504 & 1.17261 \\ \mathrm{~S} & 4.95649 & -2.14106 & 1.62754 \\ \mathrm{~S} & 4.62815 & 3.16279 & 0.55674 \\ \mathrm{C} & 6.36228 & 0.68694 & 1.48553 \\ \mathrm{C} & 7.24737 & 0.46987 & 0.25305 \\ \mathrm{H} & 6.63355 & -0.03765 & 2.25585 \\ \mathrm{H} & 6.52911 & 1.69347 & 1.87416 \\ \mathrm{O} & 6.81626 & 0.21522 & -0.85264 \\ \mathrm{O} & 8.52301 & 0.61056 & 0.61319 \\ \mathrm{C} & 9.52883 & 1.52727 & -1.44458 \\ \mathrm{C} & 9.64799 & 0.46306 & -0.35133 \\ \mathrm{H} & 9.46130 & 2.52616 & -1.00070 \\ \mathrm{H} & 8.65266 & 1.35798 & -2.07296 \\ \mathrm{H} & 10.42260 & 1.49559 & -2.07687 \\ \mathrm{C} & 10.87158 & 0.71586 & 0.53026 \\ \mathrm{H} & 10.92425 & -0.01822 & 1.34070 \\ \mathrm{H} & 10.83311 & 1.71810 & 0.96899 \\ \mathrm{H} & 11.78345 & 0.63529 & -0.06976 \\ \mathrm{C} & 9.65783 & -0.96132 & -0.91070 \\ \mathrm{H} & 10.55640 & -1.10268 & -1.52080 \\ \mathrm{H} & 8.78170 & -1.15173 & -1.53313 \\ \mathrm{H} & 9.68139 & -1.69245 & -0.09566\end{array}$

\section{$\mathrm{S}_{1}$ SDMNP}
$\begin{array}{llll}\text { C } & -0.71221 & 1.24909 & -0.56516\end{array}$
$\begin{array}{llll}\text { C } & 0.53555 & 0.72881 & -0.11365\end{array}$
$\begin{array}{llll}\text { C } & 0.60839 & -0.68458 & 0.19696\end{array}$
$\begin{array}{llll}\text { C } & -0.55204 & -1.48520 & 0.03983\end{array}$ 


\begin{tabular}{|c|c|c|c|}
\hline $\mathrm{C}$ & -1.75246 & -0.94658 & -0.39859 \\
\hline $\mathrm{C}$ & -1.81638 & 0.44998 & -0.70329 \\
\hline $\mathrm{H}$ & -0.77905 & 2.30770 & -0.80507 \\
\hline $\mathrm{H}$ & -0.49190 & -2.54528 & 0.27822 \\
\hline $\mathrm{H}$ & -2.75915 & 0.87338 & -1.04259 \\
\hline $\mathbf{N}$ & -2.90550 & -1.71287 & -0.50032 \\
\hline$U$ & -2.77820 & -2.71491 & -0.55595 \\
\hline U & -3.62265 & -1.37028 & -1.12570 \\
\hline $\mathrm{C}$ & 1.66891 & 1.55164 & 0.03316 \\
\hline 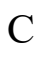 & 2.86212 & 0.99742 & 0.47691 \\
\hline$C$ & 2.94105 & -0.41354 & 0.78466 \\
\hline$C$ & 1.83128 & -1.23539 & 0.64705 \\
\hline $\mathrm{H}$ & 1.59997 & 2.60945 & -0.20385 \\
\hline $\mathrm{H}$ & 1.88924 & -2.29397 & 0.88239 \\
\hline$C$ & 4.14897 & 1.56627 & 0.72762 \\
\hline$C$ & 4.27867 & -0.67793 & 1.21876 \\
\hline $\mathrm{N}$ & 4.95564 & 0.53183 & 1.17846 \\
\hline r & 4.93244 & -2.17902 & 1.71103 \\
\hline S & 4.62776 & 3.19382 & 0.52768 \\
\hline$C$ & 6.35923 & 0.68015 & 1.48447 \\
\hline $\mathrm{f}$ & 7.25047 & 0.45767 & 0.25375 \\
\hline $\mathrm{H}$ & 6.63351 & -0.03995 & 2.26090 \\
\hline 11 & 6.53344 & 1.68857 & 1.87080 \\
\hline $\mathrm{O}$ & 6.82877 & 0.20526 & -0.85063 \\
\hline $\mathrm{O}$ & 8.52945 & 0.60265 & 0.62551 \\
\hline 4 & 9.51676 & 1.55575 & -1.42023 \\
\hline $\mathrm{C}$ & 9.63989 & 0.46933 & -0.34760 \\
\hline $\mathrm{H}$ & 9.45886 & 2.54670 & -0.95610 \\
\hline
\end{tabular}




$\begin{array}{llll}\mathrm{H} & 8.63123 & 1.40346 & -2.03992 \\ \mathrm{H} & 10.40421 & 1.53448 & -2.06380 \\ \mathrm{C} & 10.87556 & 0.69738 & 0.52629 \\ \mathrm{H} & 10.93102 & -0.05117 & 1.32380 \\ \mathrm{H} & 10.84798 & 1.69086 & 0.98576 \\ \mathrm{H} & 11.78313 & 0.62265 & -0.08291 \\ \mathrm{C} & 9.63867 & -0.94345 & -0.93989 \\ \mathrm{H} & 10.53221 & -1.07883 & -1.56039 \\ \mathrm{H} & 8.75502 & -1.11455 & -1.55777 \\ \mathrm{H} & 9.66314 & -1.69278 & -0.14061\end{array}$

$\mathrm{S}_{2} \mathrm{SDMNP}$
C $\quad-0.71221 \quad 1.24909 \quad-0.56516$
$\begin{array}{llll}\text { C } & 0.53555 & 0.72881 & -0.11365\end{array}$
$\begin{array}{llll}\text { C } & 0.60839 & -0.68458 & 0.19696\end{array}$
C $\quad-0.55204 \quad-1.48520 \quad 0.03983$
$\begin{array}{llll}\text { C } & -1.75246 & -0.94658 & -0.39859\end{array}$
$\begin{array}{llll}\text { C } & -1.81638 & 0.44998 & -0.70329\end{array}$
$\begin{array}{llll}\mathrm{H} & -0.77905 & 2.30770 & -0.80507\end{array}$
$\begin{array}{llll}\mathrm{H} & -0.49190 & -2.54528 & 0.27822\end{array}$
$\begin{array}{llll}\mathrm{H} & -2.75915 & 0.87338 & -1.04259\end{array}$
$\begin{array}{llll}\mathrm{N} & -2.90550 & -1.71287 & -0.50032\end{array}$
$\mathrm{H} \quad-2.77820 \quad-2.71491 \quad-0.55595$
$\mathrm{H} \quad-3.62265 \quad-1.37028 \quad-1.12570$
$\begin{array}{llll}\text { C } & 1.66891 & 1.55164 & 0.03316\end{array}$
$\begin{array}{llll}\text { C } & 2.86212 & 0.99742 & 0.47691\end{array}$
$\begin{array}{llll}\text { C } & 2.94105 & -0.41354 & 0.78466\end{array}$
$\begin{array}{llll}\text { C } & 1.83128 & -1.23539 & 0.64705\end{array}$ 


\begin{tabular}{|c|c|c|c|}
\hline $\mathrm{H}$ & 1.59997 & 2.60945 & -0.20385 \\
\hline $\mathrm{H}$ & 1.88924 & -2.29397 & 0.88239 \\
\hline $\mathrm{C}$ & 4.14897 & 1.56627 & 0.72762 \\
\hline $\mathrm{C}$ & 4.27867 & -0.67793 & 1.21876 \\
\hline $\mathrm{N}$ & 4.95564 & 0.53183 & 1.17846 \\
\hline S & 4.93244 & -2.17902 & 1.71103 \\
\hline S & 4.62776 & 3.19382 & 0.52768 \\
\hline $\mathrm{C}$ & 6.35923 & 0.68015 & 1.48447 \\
\hline $\mathrm{C}$ & 7.25047 & 0.45767 & 0.25375 \\
\hline $\mathrm{H}$ & 6.63351 & -0.03995 & 2.26090 \\
\hline$U$ & 6.53344 & 1.68857 & 1.87080 \\
\hline 0 & 6.82877 & 0.20526 & -0.85063 \\
\hline 0 & 8.52945 & 0.60265 & 0.62551 \\
\hline $\mathrm{C}$ & 9.51676 & 1.55575 & -1.42023 \\
\hline S & 9.63989 & 0.46933 & -0.34760 \\
\hline 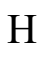 & 9.45886 & 2.54670 & -0.95610 \\
\hline $\mathrm{H}$ & 8.63123 & 1.40346 & -2.03992 \\
\hline $\mathrm{H}$ & 10.40421 & 1.53448 & -2.06380 \\
\hline $\mathrm{C}$ & 10.87556 & 0.69738 & 0.52629 \\
\hline$U$ & 10.93102 & -0.05117 & 1.32380 \\
\hline $\mathrm{H}$ & 10.84798 & 1.69086 & 0.98576 \\
\hline $\mathrm{H}$ & 11.78313 & 0.62265 & -0.08291 \\
\hline 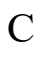 & 9.63867 & -0.94345 & -0.93989 \\
\hline $\mathrm{H}$ & 10.53221 & -1.07883 & -1.56039 \\
\hline$U$ & 8.75502 & -1.11455 & -1.55777 \\
\hline $\mathrm{H}$ & 9.66314 & -1.69278 & -0.14061 \\
\hline
\end{tabular}

$\mathrm{T}_{1}$ SDMNP 


\begin{tabular}{|c|c|c|c|}
\hline $\mathrm{C}$ & -0.74373 & 1.26253 & -0.51085 \\
\hline$C$ & 0.51140 & 0.73663 & -0.08102 \\
\hline$C$ & 0.59667 & -0.68333 & 0.18743 \\
\hline$C$ & -0.55778 & -1.49106 & 0.01235 \\
\hline $\mathrm{C}$ & -1.76397 & -0.94781 & -0.40339 \\
\hline $\mathrm{C}$ & -1.84018 & 0.45924 & -0.66596 \\
\hline 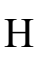 & -0.81843 & 2.32672 & -0.71762 \\
\hline $\mathrm{H}$ & -0.48664 & -2.55700 & 0.21212 \\
\hline $\mathrm{H}$ & -2.78757 & 0.88165 & -0.99011 \\
\hline $\mathrm{N}$ & -2.91147 & -1.71412 & -0.51496 \\
\hline $\mathrm{H}$ & -2.77330 & -2.71272 & -0.60732 \\
\hline $\mathrm{H}$ & -3.62286 & -1.36482 & -1.14445 \\
\hline $\mathrm{C}$ & 1.64132 & 1.56194 & 0.07873 \\
\hline$C$ & 2.83793 & 1.00060 & 0.49620 \\
\hline$C$ & 2.92746 & -0.40302 & 0.76246 \\
\hline $\mathrm{C}$ & 1.82584 & -1.23741 & 0.61197 \\
\hline $\mathrm{H}$ & 1.56862 & 2.62717 & -0.12587 \\
\hline $\mathrm{H}$ & 1.89896 & -2.30240 & 0.81479 \\
\hline $\mathrm{C}$ & 4.13046 & 1.58235 & 0.73986 \\
\hline $\mathrm{C}$ & 4.27168 & -0.66921 & 1.16788 \\
\hline $\mathrm{N}$ & 4.94771 & 0.53955 & 1.15418 \\
\hline S & 5.02526 & -2.14142 & 1.60832 \\
\hline S & 4.67307 & 3.18346 & 0.59443 \\
\hline $\mathrm{C}$ & 6.35770 & 0.68400 & 1.47090 \\
\hline $\mathrm{C}$ & 7.24869 & 0.45675 & 0.24269 \\
\hline $\mathrm{H}$ & 6.62752 & -0.02998 & 2.25484 \\
\hline $\mathrm{H}$ & 6.53050 & 1.69020 & 1.86218 \\
\hline $\mathrm{O}$ & 6.82206 & 0.17700 & -0.85807 \\
\hline
\end{tabular}




$\begin{array}{cccc}\mathrm{O} & 8.51998 & 0.61833 & 0.60555 \\ \mathrm{C} & 9.52626 & 1.50505 & -1.46513 \\ \mathrm{C} & 9.65190 & 0.46327 & -0.35139 \\ \mathrm{H} & 9.44622 & 2.51148 & -1.04087 \\ \mathrm{H} & 8.65505 & 1.31449 & -2.09435 \\ \mathrm{H} & 10.42334 & 1.47060 & -2.09251 \\ \mathrm{C} & 10.86810 & 0.74551 & 0.53120 \\ \mathrm{H} & 10.92385 & 0.02807 & 1.35616 \\ \mathrm{H} & 10.81766 & 1.75580 & 0.94969 \\ \mathrm{H} & 11.78358 & 0.66202 & -0.06282 \\ \mathrm{C} & 9.67783 & -0.97148 & -0.88257 \\ \mathrm{H} & 10.57996 & -1.11518 & -1.48677 \\ \mathrm{H} & 8.80614 & -1.18307 & -1.50444 \\ \mathrm{H} & 9.70621 & -1.68641 & -0.05346\end{array}$

\section{So SNR}

$\begin{array}{llll}\mathrm{C} & 5.08249 & 3.96034 & 2.26876 \\ \mathrm{C} & 4.54002 & 2.99662 & 1.20619 \\ \mathrm{H} & 4.76873 & 4.98243 & 2.02969 \\ \mathrm{H} & 6.17603 & 3.93877 & 2.30011 \\ \mathrm{H} & 4.70774 & 3.71400 & 3.26715 \\ \mathrm{C} & 7.32762 & 1.02477 & 1.59565 \\ \mathrm{C} & 6.04746 & 1.03615 & 0.75183 \\ \mathrm{H} & 7.61939 & 2.03886 & 1.88521 \\ \mathrm{H} & 8.14615 & 0.58799 & 1.01293 \\ \mathrm{H} & 7.20472 & 0.43187 & 2.50754 \\ \mathrm{~N} & 4.86676 & 1.58146 & 1.44208 \\ \mathrm{H} & 4.95036 & 3.25882 & 0.22809\end{array}$




$\begin{array}{llll}\mathrm{H} & 3.45381 & 3.09657 & 1.11675 \\ \mathrm{H} & 5.81602 & 0.02916 & 0.39210 \\ \mathrm{H} & 6.20122 & 1.64771 & -0.14038 \\ \mathrm{C} & 4.13732 & 0.82618 & 2.31289 \\ \mathrm{C} & 4.46326 & -0.55271 & 2.55633 \\ \mathrm{C} & 3.01873 & 1.36592 & 3.00405 \\ \mathrm{C} & 2.28339 & 0.56356 & 3.84978 \\ \mathrm{C} & 2.58869 & -0.80342 & 4.08659 \\ \mathrm{C} & 3.71293 & -1.32912 & 3.40452 \\ \mathrm{H} & 2.71700 & 2.39843 & 2.89642 \\ \mathrm{H} & 3.97043 & -2.36989 & 3.57381 \\ \mathrm{H} & 5.31679 & -1.00230 & 2.06832 \\ \mathrm{O} & 1.21266 & 1.12059 & 4.49132 \\ \mathrm{~N} & 1.85099 & -1.57079 & 4.92567 \\ \mathrm{C} & 0.46181 & 0.36058 & 5.33629 \\ \mathrm{C} & 0.81580 & -1.01819 & 5.53651 \\ \mathrm{C} & -0.60593 & 0.95854 & 5.96015 \\ \mathrm{C} & -1.44193 & 0.24224 & 6.85531 \\ \mathrm{H} & -0.81189 & 2.00417 & 5.76108 \\ \mathrm{C} & -1.12513 & -1.17791 & 7.09768 \\ \mathrm{C} & -0.01707 & -1.79224 & 6.44884 \\ \mathrm{~S} & -2.75332 & 1.03746 & 7.59963 \\ \mathrm{C} & -1.90370 & -1.96375 & 7.97223 \\ \mathrm{C} & 0.27221 & -3.14916 & 6.69052 \\ \mathrm{H} & -1.60665 & -3.29814 & 8.20035 \\ & -0.51150 & -3.89569 & 7.55548 \\ \mathrm{H} & 1.12120 & -3.59528 & 6.18460 \\ \mathrm{H} & -27738 & -4.94146 & 7.73300\end{array}$




$$
\begin{array}{llll}
\mathrm{H} & -2.74758 & -1.49556 & 8.46644 \\
\mathrm{H} & -2.22278 & -3.88090 & 8.87905
\end{array}
$$

\section{$\mathrm{S}_{1} \mathrm{SNR}$}

$\begin{array}{llll}\mathrm{C} & 5.05681 & 3.92716 & 2.29886 \\ \mathrm{C} & 4.52880 & 2.98918 & 1.21699 \\ \mathrm{H} & 4.73516 & 4.95329 & 2.09093 \\ \mathrm{H} & 6.15040 & 3.91438 & 2.33192 \\ \mathrm{H} & 4.68382 & 3.64811 & 3.28943 \\ \mathrm{C} & 7.29466 & 1.03175 & 1.62354 \\ \mathrm{C} & 6.03947 & 1.05708 & 0.75636 \\ \mathrm{H} & 7.58450 & 2.04208 & 1.92758 \\ \mathrm{H} & 8.12655 & 0.59393 & 1.06146 \\ \mathrm{H} & 7.14452 & 0.43481 & 2.52879 \\ \mathrm{~N} & 4.85468 & 1.58432 & 1.42153 \\ \mathrm{H} & 4.94276 & 3.27722 & 0.24654 \\ \mathrm{H} & 3.44177 & 3.09049 & 1.12146 \\ \mathrm{H} & 5.81903 & 0.05397 & 0.37457 \\ \mathrm{H} & 6.21442 & 1.68029 & -0.12506 \\ \mathrm{C} & 4.13619 & 0.81836 & 2.29485 \\ \mathrm{C} & 4.46505 & -0.54822 & 2.53063 \\ \mathrm{H} & 3.02042 & 1.34320 & 2.99028 \\ \mathrm{H} & 2.28972 & 0.53789 & 3.83537 \\ \mathrm{H} & 2.59621 & -0.82532 & 4.07128 \\ \mathrm{H} & 3.71774 & -1.33062 & 3.38108 \\ \mathrm{H} & 2.71087 & 2.37567 & 2.88805 \\ \mathrm{H} & 3.98400 & -2.37089 & 3.54423 \\ \mathrm{H} & -0.99638 & 2.03830\end{array}$




$\begin{array}{llll}\mathrm{O} & 1.22332 & 1.10403 & 4.47271 \\ \mathrm{~N} & 1.87465 & -1.60806 & 4.90964 \\ \mathrm{C} & 0.48991 & 0.32861 & 5.31663 \\ \mathrm{C} & 0.83237 & -1.02402 & 5.52011 \\ \mathrm{C} & -0.58934 & 0.94488 & 5.94665 \\ \mathrm{C} & -1.38403 & 0.22286 & 6.82150 \\ \mathrm{H} & -0.78522 & 1.99164 & 5.73440 \\ \mathrm{C} & -1.10184 & -1.15644 & 7.08209 \\ \mathrm{C} & 0.00309 & -1.77798 & 6.43215 \\ \mathrm{~S} & -2.73660 & 1.02147 & 7.60184 \\ \mathrm{C} & -1.89019 & -1.92623 & 7.96988 \\ \mathrm{C} & 0.27418 & -3.13537 & 6.69229 \\ \mathrm{C} & -1.60351 & -3.25187 & 8.20692 \\ \mathrm{C} & -0.51152 & -3.86214 & 7.56203 \\ \mathrm{H} & 1.11960 & -3.59194 & 6.18783 \\ \mathrm{H} & -0.28785 & -4.90830 & 7.75071 \\ \mathrm{H} & -2.73606 & -1.46006 & 8.47230 \\ \mathrm{H} & -2.22058 & -3.82618 & 8.89192\end{array}$

$\mathrm{S}_{2} \mathrm{SNR}$
$\begin{array}{llll}\text { C } & 5.05677 & 3.92580 & 2.28706\end{array}$
$\begin{array}{llll}\text { C } & 4.52218 \quad 2.98045 & 1.21354\end{array}$
$\mathrm{H} \quad 4.73456 \quad 4.94776 \quad 2.06257$
H $6.14986 \quad 3.91205 \quad 2.31652$
$\mathrm{H} \quad 4.68316 \quad 3.65939 \quad 3.28040$
$\begin{array}{llll}\text { C } & 7.28695 & 1.02157 & 1.64717\end{array}$
$\begin{array}{llll}\text { C } & 6.03810 \quad 1.04797 & 0.76952\end{array}$
$\begin{array}{llll}\mathrm{H} & 7.57342 & 2.03033 & 1.95741\end{array}$ 


\begin{tabular}{|c|c|c|c|}
\hline $\mathrm{H}$ & 8.11856 & 0.58937 & 1.08125 \\
\hline $\mathrm{H}$ & 7.13391 & 0.41674 & 2.54619 \\
\hline $\mathrm{N}$ & 4.85242 & 1.57676 & 1.43860 \\
\hline $\mathrm{H}$ & 4.93625 & 3.25411 & 0.24011 \\
\hline $\mathrm{H}$ & 3.43546 & 3.07607 & 1.12206 \\
\hline $\mathrm{H}$ & 5.81450 & 0.04714 & 0.38639 \\
\hline $\mathrm{H}$ & 6.21499 & 1.67692 & -0.10601 \\
\hline $\mathrm{C}$ & 4.12910 & 0.81668 & 2.30037 \\
\hline $\mathrm{C}$ & 4.45781 & -0.55834 & 2.53298 \\
\hline $\mathrm{C}$ & 3.01198 & 1.35017 & 2.99491 \\
\hline $\mathrm{C}$ & 2.28022 & 0.55374 & 3.84200 \\
\hline$C$ & 2.58819 & -0.81892 & 4.07773 \\
\hline$G$ & 3.71259 & -1.33363 & 3.38270 \\
\hline $\mathrm{H}$ & 2.70693 & 2.38330 & 2.88822 \\
\hline 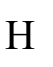 & 3.97029 & -2.37531 & 3.54765 \\
\hline $\mathrm{H}$ & 5.30685 & -1.00847 & 2.03467 \\
\hline $\mathrm{O}$ & 1.22125 & 1.12287 & 4.47659 \\
\hline $\mathrm{N}$ & 1.87502 & -1.60624 & 4.90874 \\
\hline $\mathrm{C}$ & 0.48633 & 0.34397 & 5.32220 \\
\hline $\mathrm{C}$ & 0.82681 & -1.01248 & 5.52382 \\
\hline $\mathrm{C}$ & -0.58493 & 0.95294 & 5.95259 \\
\hline $\mathrm{C}$ & -1.41764 & 0.24999 & 6.84770 \\
\hline $\mathrm{H}$ & -0.78212 & 1.99988 & 5.74666 \\
\hline $\mathrm{C}$ & -1.10762 & -1.15117 & 7.08841 \\
\hline $\mathrm{C}$ & 0.00009 & -1.76584 & 6.43210 \\
\hline S & -2.72749 & 1.06933 & 7.59049 \\
\hline $\mathrm{C}$ & -1.87707 & -1.93935 & 7.96373 \\
\hline $\mathrm{C}$ & 0.28928 & -3.12354 & 6.67386 \\
\hline
\end{tabular}




\begin{tabular}{|c|c|c|c|}
\hline $\mathrm{C}$ & -1.57755 & -3.27111 & 8.18861 \\
\hline $\mathrm{C}$ & -0.48696 & -3.86900 & 7.53978 \\
\hline $\mathrm{H}$ & 1.13736 & -3.56523 & 6.16108 \\
\hline $\mathrm{H}$ & -0.25273 & -4.91485 & 7.71691 \\
\hline $\mathrm{H}$ & -2.71983 & -1.47102 & 8.46284 \\
\hline $\mathrm{H}$ & -2.19041 & -3.85412 & 8.87044 \\
\hline \multicolumn{4}{|c|}{$\mathrm{T}_{1} \mathrm{SNR}$} \\
\hline $\mathrm{C}$ & 5.05973 & 3.92453 & 2.28690 \\
\hline $\mathrm{C}$ & 4.52546 & 2.98178 & 1.21308 \\
\hline $\mathrm{H}$ & 4.74018 & 4.94866 & 2.06816 \\
\hline $\mathrm{H}$ & 6.15307 & 3.90923 & 2.31745 \\
\hline $\mathrm{H}$ & 4.68684 & 3.65575 & 3.28009 \\
\hline $\mathrm{C}$ & 7.28845 & 1.02153 & 1.64383 \\
\hline $\mathrm{C}$ & 6.03967 & 1.04560 & 0.76848 \\
\hline $\mathrm{H}$ & 7.57353 & 2.03106 & 1.95382 \\
\hline $\mathrm{H}$ & 8.12283 & 0.58979 & 1.08147 \\
\hline $\mathrm{H}$ & 7.13658 & 0.41878 & 2.54472 \\
\hline $\mathrm{N}$ & 4.85225 & 1.57641 & 1.43350 \\
\hline $\mathrm{H}$ & 4.93815 & 3.25740 & 0.23928 \\
\hline $\mathrm{H}$ & 3.43894 & 3.07944 & 1.12024 \\
\hline $\mathrm{H}$ & 5.81692 & 0.04424 & 0.38637 \\
\hline $\mathrm{H}$ & 6.21631 & 1.67043 & -0.11048 \\
\hline $\mathrm{C}$ & 4.12821 & 0.81823 & 2.29957 \\
\hline $\mathrm{C}$ & 4.45387 & -0.55326 & 2.53529 \\
\hline $\mathrm{C}$ & 3.01166 & 1.34918 & 2.99368 \\
\hline $\mathrm{C}$ & 2.27846 & 0.55382 & 3.84023 \\
\hline $\mathrm{C}$ & 2.58433 & -0.82055 & 4.08001 \\
\hline $\mathrm{C}$ & 3.70808 & -1.32979 & 3.38556 \\
\hline
\end{tabular}




\begin{tabular}{|c|c|c|c|}
\hline [ & 2.70673 & 2.38249 & 2.88815 \\
\hline $\mathrm{H}$ & 3.96841 & -2.37079 & 3.55024 \\
\hline $\mathrm{H}$ & 5.30396 & -1.00449 & 2.03966 \\
\hline $\mathrm{O}$ & 1.21872 & 1.12448 & 4.47311 \\
\hline $\mathrm{N}$ & 1.87574 & -1.61121 & 4.90960 \\
\hline $\mathrm{C}$ & 0.48638 & 0.33741 & 5.32081 \\
\hline $\mathrm{C}$ & 0.81644 & -1.00439 & 5.52747 \\
\hline $\mathrm{C}$ & -0.59143 & 0.94809 & 5.95481 \\
\hline $\mathrm{C}$ & -1.41142 & 0.24276 & 6.84369 \\
\hline П & -0.79473 & 1.99470 & 5.75111 \\
\hline $\mathrm{C}$ & -1.11210 & -1.15200 & 7.09173 \\
\hline $\mathrm{C}$ & -0.00336 & -1.76125 & 6.43233 \\
\hline $\mathrm{S}$ & -2.71933 & 1.07185 & 7.58564 \\
\hline $\mathrm{C}$ & -1.88230 & -1.94224 & 7.96999 \\
\hline C & 0.29045 & -3.12230 & 6.67257 \\
\hline$c$ & -1.57677 & -3.26857 & 8.18907 \\
\hline $\mathrm{C}$ & -0.48195 & -3.86543 & 7.53595 \\
\hline $\mathrm{H}$ & 1.13907 & -3.55941 & 6.15742 \\
\hline $\mathrm{H}$ & -0.24804 & -4.91125 & 7.71394 \\
\hline $\mathrm{H}$ & -2.72570 & -1.47745 & 8.47151 \\
\hline $\mathrm{H}$ & -2.18545 & -3.85659 & 8.87052 \\
\hline
\end{tabular}

\section{Supporting References}

(1) Tang, J.; Wang, L.; Loredo, A.; Cole, C.; Xiao, H. Single-Atom Replacement as a General Approach Towards Visible-Light/Near-Infrared Heavy-Atom-Free Photosensitizers for Photodynamic Therapy. Chem. Sci. 2020, 11, 6701-6708.

(2) Tang, J.; Robichaux, M. A.; Wu, K.L.; Pei, J.; Nguyen, N.T.; Zhou, Y; Wensel, T.G.; Xiao, H. Single-Atom Fluorescence Switch: A General Approach toward Visible-LightActivated Dyes for Biological Imaging. J. Am. Chem. Soc. 2019, 141, 14699-14706.

(3) Frisch G. W.; Schlegel, H. B.; Scuseria, G. E.; Robb, M. A.; Cheeseman, J. R.; Scalmani, G.; Barone, V.; Petersson, G. A.; Nakatsuji, H.; Li, X.; Caricato, M.; Marenich, A. V.; Bloino, J.; Janesko, B. G.; Gomperts, R.; Mennucci, B.; Hratch, D. J., M. J. . T. Gaussian 
16 (Revision B.01). Gaussian, Inc.: Wallingford CT: Pittsburgh, PA 2016.

(4) Becke, A. D. A New Mixing of Hartree-Fock and Local Density-Functional Theories. $J$. Chem. Phys. 1993, 98, 1372-1377.

(5) Lee, C. .; Yang, W. .; Parr, R. G. Development of the Colle-Salvetti Correlation-Energy Formula into a Functional of the Electron Density. Phys. Rev. B 1988, 37, 785-789.

(6) Cancès, E. .; Mennucci, B. .; Tomasi, J. A New Integral Equation Formalism for the Polarizable Continuum Model: Theoretical Background and Applications to Isotropic and Anisotropic Dielectrics. J. Chem. Phys. 1997, 107, 3032-3041.

(7) Adamo, C. .; Barone, V. . Toward Reliable Density Functional Methods without Adjustable Parameters: The PBE0 Model. J. Chem. Phys. 1999, 110, 6158-6170.

(8) Neese, F. Software Update: The ORCA Program System, Version 4 . 0. Wiley Interdiscip. Rev. Comput. Mol. Sci. 2018, 8 (February), 4-9. https://doi.org/10.1002/wcms.1327.

(9) Dutta, A.K.; Neese, F; Izsák, R. A Simple Scheme for Calculating Approximate Transition Moments within the Equation of Motion Expectation Value Formalism. $J$. Chem. Phys. 2017, 146, 214111. https://doi.org/10.1063/1.4984618.

(10) Reichardt, C.; Vogt, R. A.; Crespo-Hernández, C. E. On the Origin of Ultrafast Nonradiative Transitions in Nitro-Polycyclic Aromatic Hydrocarbons: Excited-State Dynamics in 1-Nitronaphthalene. J. Chem. Phys. 2009, 131 (22), 0-15. https://doi.org/10.1063/1.3272536.

(11) van Stokkum, I. H. M. .; Larsen, D. S. ;; van Grondelle, R. Global and Target Analysis of Time-Resolved Spectra. Biochim. Biophys. Acta 2004, 1657, 82-104.

(12) Snellenburg, J.; Laptenok, S.; Seger, R.; Mullen, K.; Van, I.; Snellenburg, J.; Laptenok, S.; Seger, R.; Mullen, K.; A, I. V. S. G.; et al. Glotaran : A Java-Based Graphical User Interface for the R Package TIMP To Cite This Version : Glotaran : A Java -Based Graphical User Interface For. J. Stat. Softw. 2012, 49, 1-22. 